\title{
Sport or politics? Evaluative discourse analysis of the international media coverage of Sochi Olympic Games 2014
}

SVITLANA TUBALTSEVA, University of Roehampton

\begin{abstract}
This paper examines how media and news reports in particular contribute to the construction of evaluation and attitudes to the Winter Olympic Games 2014 in Sochi as a global media event owing to its controversial nature and various issues connected with these Games. The data are gathered from the prominent English-speaking newspapers in the USA and Europe representing two traditional centres of the Olympic stream and Western ideology in the contrast to the host country - Russia. In attempt to address the aim, the research explores resources of Appraisal in the articles dedicated to Sochi 2014. The study combines both qualitative and quantitative approaches to the analysis of data. The findings reveal that all newspapers construct a distinctively negative evaluation of Sochi 2014 by means of the use of emotive language and selective coverage of topics relating either to the Games or to the host country. The paper is aimed to contribute to the existing research of discourse analysis and the evaluation theory of Appraisal in the context of the Olympic discourse.
\end{abstract}

\section{KEYWORDS}

Olympic discourse, evaluation, appraisal, media coverage, thematic organization 


\section{Introduction}

The modern Olympic Games are indisputably the apotheosis of human advance in sport. With the rapid development of technology, they have become a global media event (Bernstein and Blain, 2003). The process of choosing a host country, preparation for the Games and the actual performance generate a range of newspapers articles, online news, television broadcasting, specified television programmes and tele-debates. The seeming target audience of the Games is supposed to be athletes, sport journalists and sport spectators, as according to the Olympic Charter, 'the Olympic Games are competitions between athletes in individual or team events and not between countries' (Article 6, Olympic Charter 2013). Yet, Richard Espy $(1981,7)$ points out, 'the modern Games, however, have been utilized not so much for international fairplay, peace, and understanding as for national self-interest, survival, and pride'. Despite the fact that this was stated in $80 \mathrm{~s}$, the current paper aims to explore whether it is still relevant now by conducting a discourse analysis of the recent Olympic media coverage.

For this purpose, the 2014 Winter Olympic Games in Sochi (Russia) are selected as the main research object. Being hosted by a former communist and thereby politically alien country, made these Games disputable from the beginning. Furthermore, passing of the new laws banning gay propaganda six months before the Games caused a storm of criticism by members of LGBT community and a number of foreign politicians. In addition, two bombings in the city of Volgograd, which is relatively close to the Olympic Village, two months before the Games raised concerns about the appropriateness of choice of the host country with a bad record on terrorist attacks (e.g. Russian apartment bombings in 1999, Moscow theater hostage crisis in 2002, Beslan school siege in 2004, Saint Petersburg Metro explosion in 2017 and etc.).

All these issues multiplied by ongoing geopolitical disputes involving Russia and the West generated huge debates on Sochi 2014 that were realised through a range of newspapers articles and news reports. According to Paula M. Jullian (2011, 767), no other discourse type is more ideological than the news report since this genre is not overtly political, but the selection of the event, the framing, the sources, the way the events are presented, the headings, etc. are all ideological decisions. Hence, the aim of this paper is to investigate how all factors listed above affect evaluation of the Games and attitudes constructed in media by applying methodological tools of Evaluative theory Appraisal (the overview of the theory will be provided in next sections). 


\section{Literature review}

The role of media discourse is crucial in contemporary society, as we discover about domestic and international events by means of newspapers or web services that evaluate and represent reality according to their national identity, political, social and religious stances and personal attitudes. As Edward S. Herman and Noam Chomsky $(1988,2)$ point out, media serve societal purposes, and these societal purposes include the need to inculcate and defend the economic, social, and political agenda of privileged groups that dominate the domestic society and the state through selection of topics, distribution of concerns, framing of issues, filtering of information, emphasis and tone, and by keeping debate within the bounds of acceptable premises. Sam Keen $(1986,10)$, similarly notes that 'in the beginning we create the enemy. Before the weapon comes the image. We think others to death and then invent the battle-axe or the ballistic missiles with which to actually kill them. Propaganda proceeds technology'. As a result, media discourse becomes a fruitful area for linguists and media researchers as it provides a unique combination of reportage on a particular event and intervention of ideology and culture.

One of the most evaluative piece of media discourse is news reportage. Andrew Tolson (1996, 18) defines news as a constantly updated, continuous text, which has no conclusion and which punctuates a society on a repeated, regular and scheduled basis. Jullian $(2011,767)$ develops it further and claims that no other discourse type is more ideological than the news report since this genre is not overtly political, but the selection of the event, the framing, the sources, the way the events are presented, the headings, etc. are all ideological decisions. The analysis of news reports has been massively discussed and investigated in the academic literature. Much research has been conducted on reporting news in different countries (e.g. Al-Hejin 2014; Baker et al. 2008; Baker 2011; Fang 2001; Kim 2014; Yang and Jiang, 2015). Furthermore, the ideological intervention into news reports and what effect it has on narrating events was articulated and examined by Teun A. van Dijk (1995, 1998), Roger Fowler (1991) and Norman Fairclough $(1992,1995)$.

On the account of news analysis on the Olympic discourse, there is growing interest in examining the sport event from a media analysis prospective (e.g. Higgs and Weiller 1994; Urquhart and Crossman 1999; Close, Xu, and Askew 2006; MacAloon 2008; O'Bonsawin 2010; Gong 2012; MacDonald and Hunter 2013). Most of the research focuses on sport coverage of different gender and ethnic groups during the Games. Regarding the media analysis of international news coverage of the Games, there is not such a vast range of research, 
however, a few studies are worth mentioning. For example, Susanna Hedenborga (2013) conducts the analysis of media representations, exploring how coverage intersects with gender and nationality, and devotes special attention to a comparison between the ways in which Sweden and Britain are represented in the media on the London Games 2012. Mei Yang (2015) investigates news coverage of the Beijing Games 2008 conducted by the British and the Chinese media through applying the elaborated analytical approach - corpus-based CDA.

However, no vast research has been found on the media analysis of the Olympic discourse prior to the Games themselves, as all the works mentioned above analyse coverage during the Games. I hypothesise that the articles appearing before the actual event, when the public predominantly does not have any other information or visual evidences in favor or against published facts, creates an initial image and develops preliminary attitude towards the Games. In order to examine the construal of attitudes towards the Games 2014 in the international media news reports, I apply the evaluative theory of Appraisal which is discussed in Section 3.

\section{Methodology}

As it was stated above, the main focus of the paper is evaluative meanings and attitudes constructed in international news reports through the lenses of the evaluative theory of Appraisal. The theory of Appraisal designed by J. R. Martin and David Rose (2003) offers 'one of the most comprehensive classifications available to explore linguistic evaluation' (BenitezCastro and Hidalgo-Tenorio 2019, 308). It examines texts from the perspective how an author/authors construct interpersonal meanings. This system allows authors to create alignment and solidarity with their audience by using language that expands the discourse to include other voices and opinions or, if the opposite effect is desired, to create distance from their audience by using language that contracts or closes the discourse, giving the speaker's position more weight and finality (Gales 2009, 227).

The taxonomy consists of three major branches - Attitude, Amplification and Source (see Figure 1). However, for the purpose of the pure focus on the construction of attitude in the news and due to space restriction, the paper only analyses categories of Attitude and Amplification. Attitude is represented through feelings, human characters and behavior and evaluating things. In other words, appraisal refers to emotion (Affect), ethic (Judgement) and aesthetics (Appreciation). 
Figure 1. The systematized overview of the system of Appraisal (adapted from Martin and Rose, 2003)

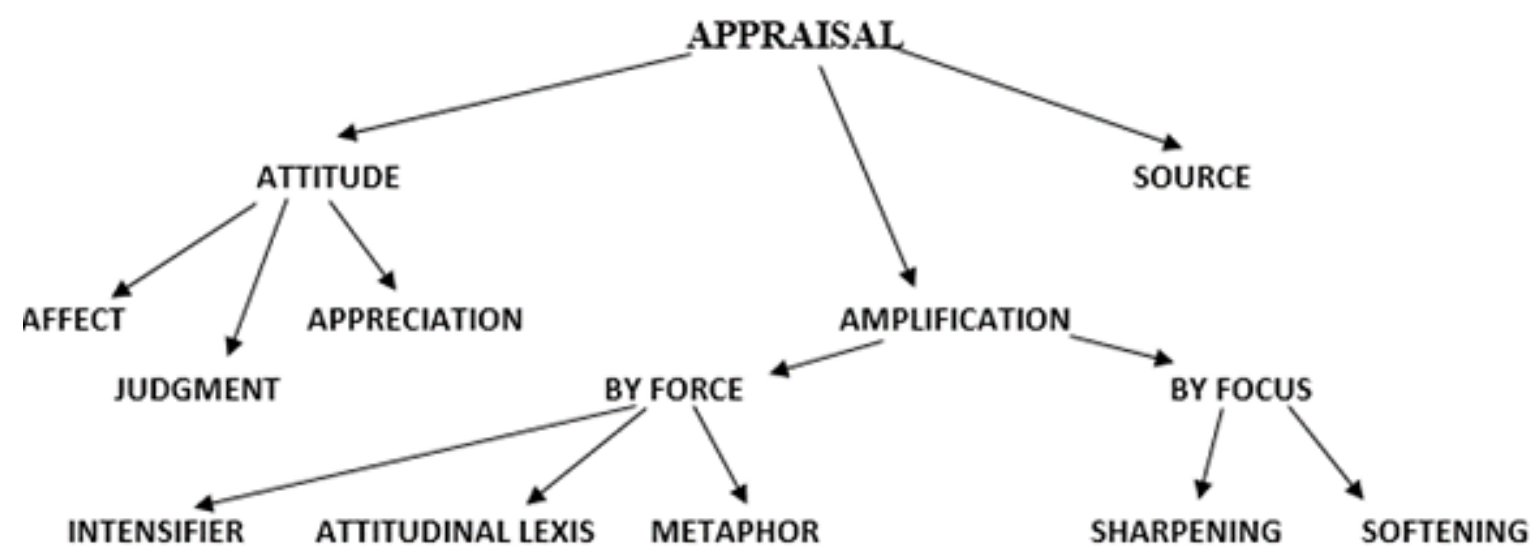

In addition to the categories focusing on what is appraised, attitudes vary in the intensity. This is called Amplification or Graduation (both terms are used interchangeably). By Amplification we mean emotive vocabulary, metaphors, idioms, adverbs, etc. Traditionally, amplification is divided according to how it is executed - by force or by focus. Amplification by force is divided into three sub-categories, namely grammatical intensifier (e.g. extremely hot; highly motivated), attitudinal lexis (a purely lexical tool that comprises itself the higher or lower degree of intensification) and metaphor (items of figurative meaning).

The second dimension of Amplification is focus. As Martin and Rose (2003, 46) point out, grading resources of this kind does not so much turn the volume up and down as sharpen and soften the boundaries between things. In other words, we might deploy sharpening or softening to the language that is traditionally non-graded (e.g. as sort of guy, kind of teacher, about four hours (softening); very first time, exactly the same, true music (sharpening)).

Overall, the system of Appraisal concentrates on semantic and lexical instantiations which can construe an evaluative meaning and potentially dispose and prime readers/listeners to build up a targeted attitude. The main advantage of the system is a set of recourses and methodological tools which help uncover covert or implicit meaning uttered by writers/speakers. This interpersonal focus of Appraisal makes it suitable for the project that explores how linguistic devices contribute to the construction of the attitude towards the Games 2014.

\section{Data selection}

For the discourse analysis, two newspapers from two geopolitical centers (USA and Europe) are selected. The rationale behind the choice of these particular regions is their political and 
sport dominance on the international scene. But, more importantly, a traditional pro-Western orientation of the modern Games might influence the way the event was reported in these regions. For this purpose, in the American context they are The New York Times (the third largest US newspaper of a predominately liberal stance) and The Washington Post (the sixth largest daily newspaper of a right-wing agenda) (Statista 2018). In the European context, the selected newspapers are the New Europe (independent, weekly published English-language newspaper based in Brussels, Belgium) and the Deutsche Welle (Germany's international online newspaper broadcasting in 30 languages around the world). The rationale for choosing these two European newspapers is their location in two political centers in Europe -Belgium, the centre of EU political life, and Germany (the largest economy of Europe).

Within these papers, the articles selection is conducted according to a few requirements. The first requirement is their thematic dedication to the Games with headlines containing such words as 'Sochi', 'the Games' and 'Olympics'. This method is supported by van Dijk (1998) who claims that the overall gist of the article is represented in headlines. The second requirement is that the period of publication should cover six months before the Games. The first reason is that six months before the Games is usually the time when all construction is over. The second reason is the passing of the new laws banning gay propaganda in Russia six months before the Games that caused a storm of criticism. Overall, 15 articles from each region are selected (30 in total) for the further discourse analysis which is discussed in the next section.

\section{Discourse analysis}

All the articles are qualitatively analysed and all the evaluative data are detected and identified. By evaluative language here, I apply the definition used by John Du Bois (2007 cited in Hunston 2011, 1). He defines it as language which indexes the act of evaluation or the act of stance-talking. In order to facilitate the process of the Appraisal analysis and its further discussion, all the evaluative data are divided according to themes. Such an analytical technique is also supported by van Dijk (1988) and Fang (2001) who argue that by analysing the themes, we gain valuable insights into not only how information was organised, but also what the journalists consider important. 
Table 1. Topics and sub-topics in the articles

\begin{tabular}{|l|l|l|l|}
\hline Gay issues & Sochi issues & $\begin{array}{l}\text { International } \\
\text { reaction }\end{array}$ & Russia \\
\hline Russian law & $\begin{array}{l}\text { General view on } \\
\text { Sochi }\end{array}$ & & Russia \\
\hline Gays in Russia & Local residents & & Human rights \\
\hline $\begin{array}{l}\text { International } \\
\text { representation of gays }\end{array}$ & Venues/facilities & & Politics \\
\hline & Hotels & & Putin \\
\hline & Climate & & Economics \\
\hline & & & Police/Justice \\
\hline & & & Pussy Riot \\
\hline & & Soviet Past \\
\hline & & & People/culture \\
\hline & & Press/media \\
\hline
\end{tabular}

As a result, four topics, namely 'Gay Issues', 'Sochi Issues', 'International Reaction' and 'Russia', are identified as major themes of the analysed articles, which are not accidental as they narrate the main international and domestic issues of the 2014 Games. Considering the fact that these themes are quite broad, and the analysed data showed evaluation of different aspects of these issues, they are divided into sub-themes, with the exception of the theme 'International Reaction' (see Table 1).

Having undertaken preliminary preparations for a more detailed investigation, the next step of the discourse analysis is to scrutinise evaluative language items from the perspective of Appraisal theory and the polarity of utterances (negative or positive stance). All the findings are categorised and organised in summarising tables. In the following sub-sections, I will focus on discursive patterns and trends of attitudinal language in two different national contexts.

\section{American news coverage}

In this sub-section, I will discuss what evaluative patterns and trends are identified in The New York Times and The Washington Post. In terms of the distribution of analytical categories, The Washington Post tends to use the resources of Appreciation more frequently than Affect and Appreciation (see Table 2). The most commented theme in terms of Appreciation is Sochi as the geographical location of the Games. Hence, it is worth discussing Appreciation instances in more details below. 
Table 2. The categories of appraisal in The Washington Post

\begin{tabular}{|c|c|c|c|c|c|c|c|c|c|c|c|c|c|c|c|}
\hline \multirow[b]{3}{*}{ 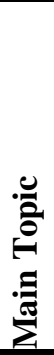 } & \multirow{3}{*}{ Subtopics } & \multicolumn{7}{|c|}{$\begin{array}{l}\text { Positive connotation } \\
\end{array}$} & \multicolumn{7}{|c|}{ Negative connotation } \\
\hline & & \multicolumn{3}{|c|}{ Attitude } & \multicolumn{4}{|c|}{ Amplification } & \multicolumn{3}{|c|}{ Attitude } & \multicolumn{4}{|c|}{ Amplification } \\
\hline & & 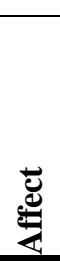 & 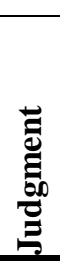 & 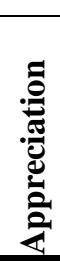 & 窇 & & $\frac{a}{\frac{a}{2}}$ & 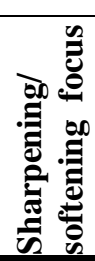 & 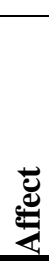 & 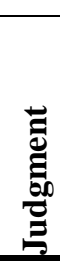 & 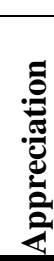 & : & & $\frac{\grave{c}}{\frac{a}{2}}$ & 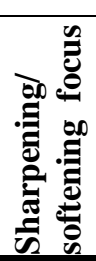 \\
\hline \multirow{3}{*}{$\frac{2}{3}$} & Russian law & & & & & & & & & & 1 & & 1 & & \\
\hline & Gays in Russia & & 1 & 2 & & 3 & & & 2 & & 1 & 1 & 1 & & \\
\hline & $\begin{array}{l}\text { International } \\
\text { representation of } \\
\text { gays }\end{array}$ & & & & & & & & & & & & & & \\
\hline \multirow{6}{*}{ 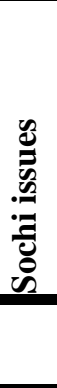 } & Sochi & & & 3 & & 1 & & & 4 & & 36 & 9 & 17 & 3 & \\
\hline & Local residents & & 1 & 2 & 1 & & & 1 & 1 & & 4 & 2 & 2 & & \\
\hline & Venues/facilities & & & & & & & & & & 11 & 3 & 2 & 2 & \\
\hline & Hotels & & & & & & & & 1 & 1 & 8 & 2 & 5 & & \\
\hline & Climate & & & 5 & 1 & 1 & & & & & 7 & 4 & 1 & 2 & \\
\hline & $\begin{array}{l}\text { International } \\
\text { reaction }\end{array}$ & & & & & & & & & 1 & 6 & 2 & 3 & 1 & \\
\hline \multirow{10}{*}{ 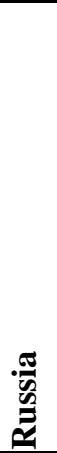 } & Russia & & & & & & & & 2 & 2 & 18 & & 13 & 2 & \\
\hline & Human rights & & & & & & & & 1 & & 4 & & & & \\
\hline & Politics & & & & & & & & & 1 & 2 & & 2 & & \\
\hline & Putin & & & & & & & & & 3 & 4 & & 4 & & \\
\hline & Economics & & & & & & & & & & & & & & \\
\hline & Police/Justice & & & & & & & & & & & & & & \\
\hline & Pussy Riot & & 3 & & & 3 & & & & & & & & & \\
\hline & Soviet Past & & & & & & & & & & 2 & & 2 & & \\
\hline & People/culture & & & & & & & & 1 & & 1 & & 2 & & \\
\hline & Press/media & & & & & & & & & & 2 & & 2 & & \\
\hline
\end{tabular}

Instead of forming the appreciation of Sochi by means of negative adjectives, The Washington Post uses contrastive adjectives or antonyms in a sentence. Even the use of positive adjectives, that are supposed to change the connotation of the whole phrase, has an opposite effect. They seem to emphasise the negative side of described events and makes sentences sound even more negative and corrosive.

\begin{tabular}{|c|c|}
\hline The grim and the gorgeous & Appreciation \\
\hline in a sort of charming, broken English & $\begin{array}{c}\text { Appreciation } \\
\text { Amplification (softening } \\
\text { focus) }\end{array}$ \\
\hline stunning in its stony, ruined way & $\begin{array}{c}\text { Appreciation } \\
\text { broken concrete next to soaring opulence }\end{array}$ \\
\hline
\end{tabular}


In addition to the abundant Appreciation, the theme has the highest number of Affect among all other topics. Noticeably, all of them are used in the negative comments (e.g. cautioned wearing their uniforms and gear outside venues; full of suppression, apprehension; fired up about these Games). The multiple use of Appreciation accompanied with some occurrence of Affect seems to indicate that the newspaper tended to evaluate Sochi by means of commenting on its drawbacks, but by referring to the feeling people have on Sochi, that seems to be more emotive.

Considering the category of Judgment, it is best represented in two themes - 'Putin' and 'Pussy Riot'. The latest is worth discussing in detail, as Judgment there is amplified by attitudinal lexis. The use of positive judgments intensified by particular lexis (e.g. magnificent, gloriously, heroic) in the comments on Russian opposition group seems to indicate the political position of the newspaper on Russia that comprises the criticism of the Government and support for opposition forces.

\begin{tabular}{|c|c|}
\hline $\begin{array}{c}\text { magnificent human rights spokeswoman from } \\
\text { Pussy Riot }\end{array}$ & $\begin{array}{c}\text { Judgment } \\
\text { Amplification (attitudinal lexis) }\end{array}$ \\
\hline gloriously brave and witty & Judgment \\
& $\begin{array}{c}\text { Amplification (attitudinal lexis) } \\
\text { (intensifier) }\end{array}$ \\
\hline heroic human rights stance & Judgment \\
& Amplification (attitudinal lexis) \\
\hline
\end{tabular}

Another category of Amplification deployed in The Washington Post is metaphor. It is widely used solely in the negative comments (see examples below). Interestingly, some metaphors include references to world-known films and Russian history, although their most negative and disgraceful manifestations (e.g. weapons in The Matrix and Potemkin village).

\begin{tabular}{|c|c|}
\hline a bubble so closed and devoid of reality & $\begin{array}{c}\text { Appreciation } \\
\text { Amplification } \\
\text { (metaphor) }\end{array}$ \\
\hline $\begin{array}{c}\text { men with more weapons than Keanu Reeves when he } \\
\text { went through the metal detector in "The Matrix. }\end{array}$ & Appreciation \\
\hline $\begin{array}{c}\text { Potemkin village, an elaborate facade built to impress } \\
\text { foreign passersby and to enhance the image of a small, } \\
\text { odd, chill-faced man who likes to pose menacingly } \\
\text { shirtless in order to seem much taller than he actually } \\
\text { is }\end{array}$ & $\begin{array}{c}\text { Judgment } \\
\text { Appreciation } \\
\text { (intensifier) } \\
\text { (metaphor) } \\
\text { (attitudinal lexis) }\end{array}$ \\
\hline
\end{tabular}


The analysis of appraisal in The New York Times does not reveal fundamental differences from The Washington Post, although some unique patterns are still observed. Similar to The Washington Post, The New York Times shows the dominance of Appreciation in the most of topics (see Table 3). The only theme where Appreciation does not have the highest point was 'International reaction'. Interestingly, the number of Affect in this theme is almost twice as high as the number of Appreciation. This is quite a striking pattern considering the overall dominance of the latter.

Table 3. The categories of appraisal in The New York Times

\begin{tabular}{|c|c|c|c|c|c|c|c|c|c|c|c|c|c|c|c|}
\hline \multirow[b]{3}{*}{ 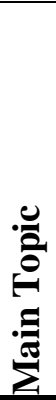 } & \multirow{3}{*}{ Subtopics } & \multicolumn{7}{|c|}{\begin{tabular}{|l|} 
Positive connotation \\
\end{tabular}} & \multicolumn{7}{|c|}{ Negative connotation } \\
\hline & & \multicolumn{3}{|c|}{ Attitude } & \multicolumn{4}{|c|}{ Amplification } & \multicolumn{3}{|c|}{ Attitude } & \multicolumn{4}{|c|}{ Amplification } \\
\hline & & $\sum^{\stackrel{e}{e}}$ & 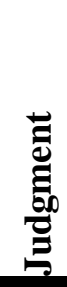 & 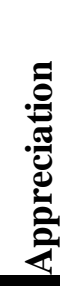 & 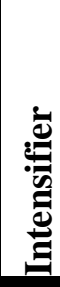 & 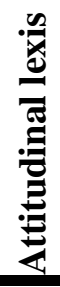 & $\frac{\frac{\dot{g}}{0}}{\frac{\pi}{\tilde{J}}}$ & 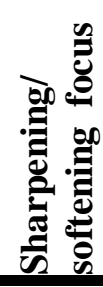 & 递 & 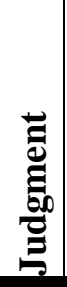 & 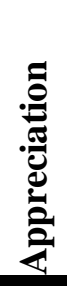 & 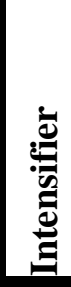 & 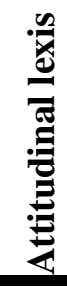 & $\begin{array}{l}\dot{a} \\
\frac{a}{2} \\
\frac{\pi}{0} \\
\sum\end{array}$ & 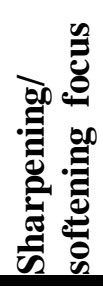 \\
\hline \multirow{3}{*}{ 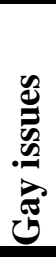 } & Russian law & & & 1 & 1 & 1 & & & & & 15 & 6 & 5 & & \\
\hline & Gays in Russia & 1 & 1 & & & & & & 1 & & & 1 & & & \\
\hline & $\begin{array}{l}\text { International } \\
\text { representation of } \\
\text { gays }\end{array}$ & & 1 & 2 & & & & & & & & & & & \\
\hline \multirow{6}{*}{ 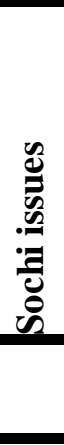 } & Sochi & & & $\begin{array}{l}1 \\
1\end{array}$ & 2 & 3 & & & 1 & & 25 & 4 & 9 & 3 & \\
\hline & Local residents & & & & & & & & & & & & & & \\
\hline & Venues/facilities & & & 5 & 1 & 1 & & 1 & & & 23 & 3 & 5 & 3 & 6 \\
\hline & Hotels & & 1 & 1 & & & & & 1 & & 5 & 2 & 2 & & 1 \\
\hline & Climate & & & 1 & & & & & & & 1 & & & & \\
\hline & $\begin{array}{l}\text { International } \\
\text { reaction }\end{array}$ & 1 & & 1 & & & & & 7 & 1 & 4 & 3 & 3 & 1 & 1 \\
\hline \multirow{10}{*}{ 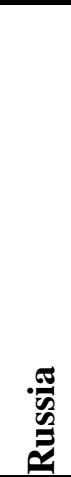 } & Russia & & & & & & & & & & 1 & & 1 & & \\
\hline & Human rights & & & & & & & & & & & & & & \\
\hline & Politics & & & & & & & & & & 3 & 2 & 1 & & \\
\hline & Putin & & & & & & & & & & 1 & & & 1 & \\
\hline & Economics & & & & & & & & & & 4 & 1 & 2 & & 1 \\
\hline & Police/Justice & & & & & & & & & & & & & & \\
\hline & Pussy Riot & & & & & & & & & & & & & & \\
\hline & Soviet Past & & & & & & & & & & & & & & \\
\hline & People/culture & & & & & & & & & 1 & & & 1 & & \\
\hline & Press/media & & & & & & & & & & & & & & \\
\hline
\end{tabular}

The multiple use of Affect in this theme indicates that the paper tends to use emotive language to emphasise the negative evaluation of the Games. In some cases, Affect is accompanied with various kinds of Amplification that intensified the language (e.g. adamantly, all things, so). 
This strategy looks consistent with The Washington Post which deploys the same strategy but in the topic 'Sochi'.

\begin{tabular}{|c|c|}
\hline Outraged & $\begin{array}{c}\text { Affect } \\
\text { Amplification (attitudinal } \\
\text { lexis) }\end{array}$ \\
\hline boycott watching the Olympics on TV & Affect \\
\hline so reluctantly (show the Winter Games in his bar) & $\begin{array}{c}\text { Affect } \\
\text { Amplification (intensifier) }\end{array}$ \\
\hline adamantly opposed & $\begin{array}{c}\text { Affect } \\
\text { Amplification (intensifier) }\end{array}$ \\
\hline boycott all things Russian & $\begin{array}{c}\text { Affect } \\
\text { Amplification (sharpening } \\
\text { focus) }\end{array}$ \\
\hline Cautioned & Affect \\
\hline concern about the quality of medical care in the region & Affect \\
\hline
\end{tabular}

Another feature that unites The New York Times and The Washington Post is the use of contrasts, though used more in The Washington Post (e.g. peculiar mix of grandiosity and bungling; luxury hotels with lobbies stuffed with inventory, frenetic employees and unnerved hospitality professionals; the mall's doors are open, though the individual stores are not). They are predominantly deployed in the themes 'Venues/Facilities' and 'Hotels'. This gives an initial impression that the paper is more disposed to the Games, although in reality it endorses the negative image of the Games.

\begin{tabular}{|c|c|}
\hline $\begin{array}{c}\text { word "Mystery" on the bottom of the television? Is that } \\
\text { the brand name? Or a sly invitation to wonder why it does } \\
\text { not work? }\end{array}$ & $\begin{array}{c}\text { Appreciation } \\
\text { Amplification (metaphor) }\end{array}$ \\
\hline $\begin{array}{c}\text { It actually seems like some small, spiteful pharaoh is } \\
\text { building himself the greatest pyramid in the world } \\
\text { makes subterranean hipster bars in Brooklyn seem } \\
\text { desperate for attention }\end{array}$ & $\begin{array}{c}\text { Appreciation } \\
\text { Amplification (attitudinal } \\
\text { lexis) } \\
\text { (metaphor) }\end{array}$ \\
\hline $\begin{array}{r}\text { short-lived McDonald's sandwich } \\
\text { (Sochi Olympics slogan) }\end{array}$ & $\begin{array}{c}\text { Appreciation } \\
\text { Amplification (metaphor) }\end{array}$ \\
\hline $\begin{array}{c}\text { Appreciation } \\
\text { Amplification } \\
\text { (metaphor) }\end{array}$ \\
\hline $\begin{array}{c}\text { word "Mystery" on the bottom of the television? Is that } \\
\text { the brand name? Or a sly invitation to wonder why it does } \\
\text { not work? }\end{array}$ & $\begin{array}{c}\text { Appreciation } \\
\text { Amplification (metaphor) }\end{array}$ \\
\hline
\end{tabular}

The case where both newspapers show a similar trend is the use of metaphors in the negative comments. In the case of The New York Times, they are mostly in such themes as 'Sochi' and 'Venues/Facilities'. If we draw a parallel with The Washington Post, the metaphors in The New York Times are less corrosive and refers more to American realis (McDonald's sandwich, bars in Brooklyn). This might reflect a possible orientation of the paper - domestic readership or a 
more international one. Alternatively, it might show the emphasis the author is aiming to have - to contrast American and Russian cultures.

The most striking difference between two papers is the use of sharpening focus. On the contrary to The Washington Post that barely utilised this category, The New York Times shows multiple incidents in the topic of 'Venues/Facilities'. The use of this category seems to demonstrate that the author aims to emphasise the numerous drawbacks of the Games (e.g. fair question, and just one of dozens; not only is Building 10 hard to find; none of the buildings have names).

Overall, both American papers demonstrate the negative appraisal of the Games and are more openly antagonistic, though The New York Times has more positive appraisal. The difference in the themes coverage shows that The Washington Post is the most critical towards Russia in general, whereas The New York Times appears to attack the quality of Sochi facilities and reports on the international reaction to the Games. Apart from this, both newspapers show many similar trends in the use of linguistic strategies (e.g. the use of contrastive adjectives, the use of metaphors and attitudinal lexis relating to American and Russian realis).

\section{European news coverage}

The European media produce significantly fewer evaluative comments than the American press. This particularly concerns the New Europe. The paper demonstrates the lack of Amplification in positive comments (e.g. five samples of intensifier and one of attitudinal lexis) and slightly more variety in negative comments (see Table 4). In terms of Attitude, the paper seems to follow the American trend and deploys mostly Appreciation. The categories of Affect and Judgment are barely presented in the paper. Therefore, it seems relevant to focus on the use of Appreciation which dominates in the discourse.

Despite the highest number of Appreciation in the topic 'Sochi', the second largest topic, 'Russia', is worth discussing. The reason behind this is the orientation of the comments that mostly refer to the Caucasus wars. This is not surprising as the Games were located in South Caucasus which is not far from a terrorist base. The shift of themes indicates the author's intention to focus on the most controversial and notoriously famous events to construct a negative attitude to Russia. In addition, the vast use of the resources attitudinal lexis and intensifiers might prime readers to associate Russia with terrorists and radical Muslims. 


\begin{tabular}{|c|c|}
\hline $\begin{array}{c}\text { the terror the Islamists spread in some regions of the } \\
\text { North Caucasus Russian autonomous republics is } \\
\text { equated with the abuses of the Russian government } \\
\text { (report) }\end{array}$ & $\begin{array}{c}\text { Appreciation } \\
\text { Amplification } \\
\text { (attitudinal lexis) }\end{array}$ \\
\hline $\begin{array}{c}\text { Government abuses in counter-insurgency operations } \\
\text { include enforced disappearances, torture, and } \\
\text { extrajudicial executions. These abuses go unpunished }\end{array}$ & $\begin{array}{c}\text { Appreciation } \\
\text { Amplification } \\
\text { (attitudinal lexis) }\end{array}$ \\
\hline $\begin{array}{c}\text { actually much more complicated than this simplifying } \\
\text { picture (the situation in the North Caucasus) }\end{array}$ & $\begin{array}{c}\text { Appreciation } \\
\text { Amplification (intensifier) }\end{array}$ \\
\hline $\begin{array}{c}\text { Repeatedly (North Caucasian Muslim fundamentalist } \\
\text { guerrillas attacked and killed civilians) }\end{array}$ & $\begin{array}{c}\text { Appreciation } \\
\text { Amplification (intensifier) }\end{array}$ \\
\hline $\begin{array}{c}\text { spread a reign of terror (North Caucasian Muslim) } \\
\text { Appreciation } \\
\text { Amplification (metaphor) } \\
\text { (attitudinal lexis) }\end{array}$ \\
\hline $\begin{array}{c}\text { spreading an intolerant version of Wahhabi Islam } \\
\text { (North Caucasian Muslim fundamentalist guerrillas) }\end{array}$ & \begin{tabular}{c} 
Appreciation \\
\hline
\end{tabular}
\end{tabular}

However, it is worth noting that the paper still gives a couple of positive comments on the Russian security and their ability and readiness to guarantee safety during the Olympics. The only incident of Judgment comprises not only a comment on Ramzan Kadyrov, the Head of the Chechen Republic, which is at the center of the Caucasian wars, but also the evaluation of the branch of Islam he practices. A positive appraisal of the latter (e.g. traditional, tolerant) indicates a contrast between two branches and acknowledges that Islam is not a solely radical religion.

\begin{tabular}{|c|c|}
\hline $\begin{array}{c}\text { a defender of the traditional Sufi, tolerant branch } \\
\text { of Islam (Putin's protége Ramzan Kadyrov) }\end{array}$ & $\begin{array}{c}\text { Judgment } \\
\text { Appreciation }\end{array}$ \\
\hline $\begin{array}{c}\text { "ready" for the security challenge presented by the } \\
\text { game }\end{array}$ & Appreciation \\
\hline
\end{tabular}

As it is mentioned below, the category of Affect is scarcely represented in The New Europe. The only theme including a couple of incidents is International reaction. Despite the fact that they are both deployed in the negative comments, one of them does not appraise the Games, but instead the International Olympic Committee (IOC) president (e.g. unhappy with the performance of Rogge as IOC president). He is criticised by human activist for his support of Sochi 2014. It appears to be quite difficult to analyse this comment, as despite its definite negative connotation, it does not criticise Sochi, but instead demonstrates that not all international leaders condemn the Games. 
Table 4. The categories of appraisal in the New Europe

\begin{tabular}{|c|c|c|c|c|c|c|c|c|c|c|c|c|c|c|c|}
\hline \multirow[b]{3}{*}{ 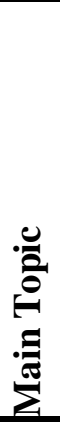 } & \multirow{3}{*}{ Subtopics } & \multicolumn{7}{|c|}{ Positive connotation } & \multicolumn{7}{|c|}{ Negative connotation } \\
\hline & & \multicolumn{3}{|c|}{ Attitude } & \multicolumn{4}{|c|}{ Amplification } & \multicolumn{3}{|c|}{ Attitude } & \multicolumn{4}{|c|}{ Amplification } \\
\hline & & 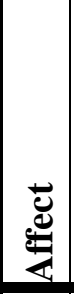 & 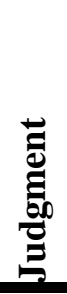 & & 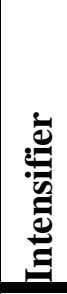 & 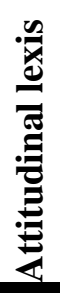 & $\frac{\grave{a}}{\frac{\pi}{2}}$ & 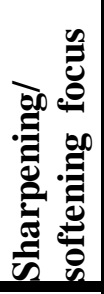 & 苞 & 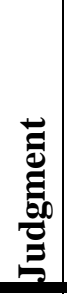 & 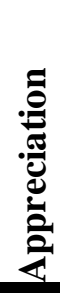 & 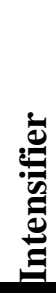 & 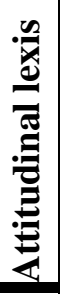 & 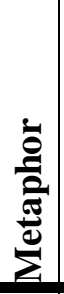 & 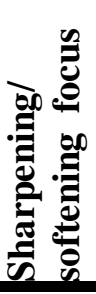 \\
\hline \multirow{3}{*}{ 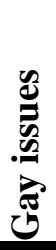 } & Russian law & & & 1 & & & & & & & 5 & & 1 & & \\
\hline & Gays in Russia & & & & & & & & & & 3 & & & & \\
\hline & $\begin{array}{l}\text { International } \\
\text { representation of } \\
\text { gays }\end{array}$ & & & & & & & & & & & & & & \\
\hline \multirow{6}{*}{ 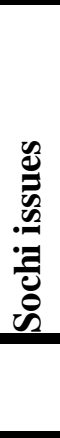 } & Sochi & & 1 & 9 & 2 & & 1 & & & & $\begin{array}{l}2 \\
2\end{array}$ & 5 & 6 & 1 & \\
\hline & Local residents & & & & & & & & & & 2 & & 1 & 1 & \\
\hline & Venues/facilities & & & 1 & 1 & & & & & & 3 & & & & \\
\hline & Hotels & & & & & & & & & & & & & & \\
\hline & Climate & & & & & & & & & & & & & & \\
\hline & $\begin{array}{l}\text { International } \\
\text { reaction }\end{array}$ & 1 & 1 & 4 & 1 & & & & 2 & 1 & $\begin{array}{l}1 \\
2\end{array}$ & 4 & & & \\
\hline \multirow{10}{*}{ 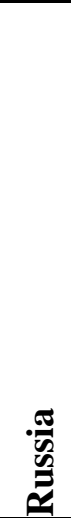 } & Russia & & 1 & 2 & & & & & & & $\begin{array}{l}1 \\
6\end{array}$ & 3 & 2 & 1 & \\
\hline & Human rights & & & & & & & & 1 & & 8 & 1 & 6 & 1 & \\
\hline & Politics & & & & & & & & & & & & & & \\
\hline & Putin & & & & & & & & & & & & & & \\
\hline & Economics & & & 3 & 1 & & & & & & 6 & 2 & & & \\
\hline & Police/Justice & & & & & & & & & & 1 & & & & \\
\hline & Pussy Riot & & & & & & & & & & & & & & \\
\hline & Soviet Past & & & & & & & & & & & & & & \\
\hline & People/culture & & & & & & & & & & & & & & \\
\hline & Press/media & & & & & & & & & & 8 & 1 & 4 & 2 & \\
\hline
\end{tabular}

Considering the categories of Appraisal presented in the Deutsche Welle, it does not reveal any striking differences from the New Europe in terms of variety of categories (see Table 5). The German newspaper shows a traditional dominance of Appreciation and the limited use of Affect and Judgment. The only thing that stands out is a larger scale of appraisal. Another pattern that distinguishes the Deutsche Welle is a considerable amount of attitudinal lexis. This is particularly salient in the topic 'Russia', where apart from the lexis other resources of Amplification are also used. 
Table 5. The kinds of attitude in The Deutsche Welle

\begin{tabular}{|c|c|c|c|c|c|c|c|c|c|c|c|c|c|c|c|}
\hline \multirow[b]{3}{*}{ 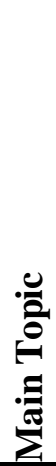 } & \multirow{3}{*}{ Subtopics } & \multicolumn{7}{|c|}{ Positive connotation } & \multicolumn{7}{|c|}{ Negative connotation } \\
\hline & & \multicolumn{3}{|c|}{ Attitude } & \multicolumn{4}{|c|}{ Amplification } & \multicolumn{3}{|c|}{ Attitude } & \multicolumn{4}{|c|}{ Amplification } \\
\hline & & $\sum_{\bar{Z}}^{\bar{e}}$ & 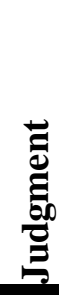 & 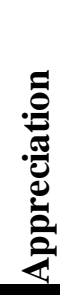 & 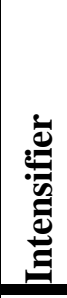 & 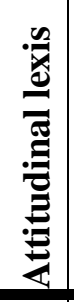 & 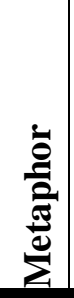 & 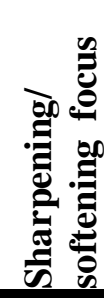 & $\sum_{\bar{z}}^{\bar{e}}$ & 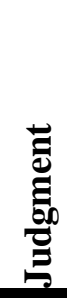 & 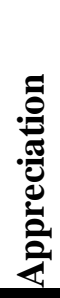 & : & 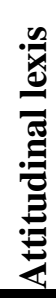 & $\frac{\frac{\dot{\theta}}{0}}{\frac{\pi}{\tilde{J}}}$ & 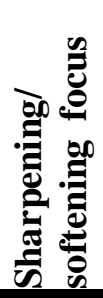 \\
\hline \multirow{3}{*}{ 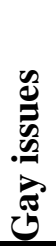 } & Russian law & & & 3 & & & & 1 & & & 1 & & & & \\
\hline & Gays in Russia & & & 2 & & & & 1 & & & 4 & 3 & & & \\
\hline & $\begin{array}{l}\text { International } \\
\text { representation of } \\
\text { gays }\end{array}$ & & & & & & & & & & & & & & \\
\hline \multirow{6}{*}{ 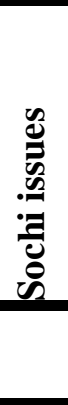 } & Sochi & & & 2 & & & & & 1 & & 19 & 3 & 4 & 2 & \\
\hline & Local residents & & & & & & & & 2 & & 2 & 1 & 2 & 1 & \\
\hline & Venues/facilities & & & 1 & & & & & & & & & & & \\
\hline & Hotels & & & 2 & & & & & & & & & & & \\
\hline & Climate & & & 8 & 2 & 2 & & & 1 & & 11 & 2 & 3 & 1 & \\
\hline & $\begin{array}{l}\text { International } \\
\text { reaction }\end{array}$ & & & 1 & 1 & & & 1 & 2 & & 4 & 1 & 1 & 1 & \\
\hline \multirow{10}{*}{ 部 } & Russia & & & 7 & 2 & 1 & & & & 1 & 21 & 5 & 7 & 1 & \\
\hline & Human rights & & & & & & & & & & 9 & 1 & 5 & & \\
\hline & Politics & & & & & & & & & & 4 & & 2 & & \\
\hline & Putin & 1 & & 1 & & & 1 & & & & & & & & \\
\hline & Economics & & & 1 & & & & & & & 3 & 1 & & & \\
\hline & Police/Justice & & & & & & & & 1 & & 2 & & 1 & & \\
\hline & Pussy Riot & & & & & & & & & & & & & & \\
\hline & Soviet Past & & & & & & & & & & & & & & \\
\hline & People/culture & 2 & & & & & & & & & & & & & \\
\hline & Press/media & & 1 & & & & & 1 & & 1 & 5 & 1 & 2 & & \\
\hline
\end{tabular}

The theme 'Russia' is also quite remarkable owing to what is narrated there. Similar to the New Europe, the Deutsche Welle also refers to the Caucasian wars, though it accounts only for one comment in the topic 'Russia' (e.g. fears of Islamist terror). Instead, it focuses more on main issues of the modern Russia such as corruption, media censorship, oppression of the opposition, etc. (see examples below). The use of the large amount of appraisal accompanied with Amplification in almost all comments greatly emphasise the negative evaluation. 


\begin{tabular}{|c|c|}
\hline dark sides of the new Russia & $\begin{array}{c}\text { Amplification (metaphor) } \\
\text { Appreciation }\end{array}$ \\
\hline $\begin{array}{c}\text { the corruption, the arrogance of public officials, the } \\
\text { arbitrariness of government organizations, the critical human } \\
\text { rights situation, the environmental destruction, media } \\
\text { censorship, homophobic laws, unfair treatment of migrant } \\
\text { workers, ethnic conflicts in the Northern Caucasus, the } \\
\text { unfinished facilities and much more }\end{array}$ & $\begin{array}{c}\text { Appreciation } \\
\text { Amplification (attitudinal lexis) } \\
\text { (intensifier) }\end{array}$ \\
\hline $\begin{array}{c}\text { no real rule of law; that the opposition is oppressed; that } \\
\text { human rights activists, lawyers and journalists are thrown in } \\
\text { jail if they criticize the government }\end{array}$ & $\begin{array}{c}\text { Amplification (attitudinal lexis) } \\
\text { fear of repression }\end{array}$ \\
\hline $\begin{array}{c}\text { Appreciation } \\
\text { exclusively to discredit and to scare people (The foreign agent } \\
\text { law) }\end{array}$ & $\begin{array}{c}\text { Amplification (attitudinal lexis) } \\
\text { noppreciation } \\
\text { Affect }\end{array}$ \\
\hline nature of democracy in Russia & Amplification (intensifier) \\
\hline & Appreciation \\
\hline & Appreciation \\
\hline
\end{tabular}

Considering the positive comments on Russia, another pattern is identified. The majority of the comments depict modern changes in Russia (e.g. strong and modern Russia; significant change of Russia). Some of changes are related to the Russian President Putin (e.g. under his rule was modern and progressive). This is quite surprising as this topic is also abundant of negative evaluation that mostly condemns the Russian Government and its policies (see examples above). This indicates that the Deutsche Welle does not have a clear definitive position on Putin that leads to the presence of both positive and negative appraisal.

The reference to Putin is also noticeable in the New Europe, though in the topic 'Sochi'. The Games are appraised through its association with the President (e.g. his personal project) and his personal contribution to hosting the Games (see the example below). The use of judgment of Putin in the topic 'Sochi' signifies that the Games are appraised through the evaluation of politics of the host country. This also exemplifies the shift of themes previously noticed in the topic 'Russia'.

\begin{tabular}{|c|c|}
\hline $\begin{array}{c}\text { Culmination of years-long effort by Russian President } \\
\text { Vladimir Putin, who has bet much of his personal }\end{array}$ & $\begin{array}{c}\text { Appreciation } \\
\text { prestige and Russia's modern image on hosting } \\
\text { successful Games at Sochi }\end{array}$ \\
$\begin{array}{c}\text { Amplification } \\
\text { (intensifier) }\end{array}$ \\
\hline
\end{tabular}

Meanwhile, the Deutsche Welle demonstrates another intriguing pattern in the topic 'Sochi'. Instead of referring to Putin, it shows a reference to the previous Games, namely Moscow 1980 and Beijing 2008. The choice of these particular Games does not seem to be random as both of them have obtained the most international criticism. Thus, drawing parallels between them and 
Sochi emphasise that despite a modern view of Russia, the Games are still perceived as highly controversial.

\begin{tabular}{|c|c|}
\hline China 2008 & Appreciation \\
\hline turned Sochi-2014 into Moscow-1980 & Appreciation \\
\hline
\end{tabular}

In conclusion, European media shows the overall negative attitude towards Sochi 2014, although the Deutsche Welle proves to be more of a protagonist of the Games. Another important finding is the limited number of comments that lead to the lack of variety of the Appraisal categories presented in both newspapers which highlights a more neutral position of Europe.

\section{Conclusion}

The individual analysis of the news reports in two different regions demonstrates that all national media have a distinctively negative evaluative load of the 2014 Games, however, the ways they execute it vary. The American newspapers have many commonalities, among which are a larger theme coverage than in European media and a vast variety of linguistic realisations (the categories of Appraisal). In turn, European media show a tendency to omit commenting on Russian issues (which were heavily appraised in the American media) which indicates the attempts of the paper to sound more neutral.

In terms of the categories of Appraisal, all the newspapers show a salient feature - the dominance of Appreciation. This is not unexpected as the main appraised item is the event (the Olympic Games) and events are usually appraised by means of Appreciation. Therefore, the scarce use of Affect over Judgment is highly significant and influential. Remarkably, all the newspapers use Affect and Judgment in the themes 'International reaction', 'Russian law', 'Gays in Russia' and 'Putin' which are the most controversial and ambiguous.

By contrast, the resources of Amplification are presented differently in the newspapers. The American media show abundant incidents of attitudinal lexis and intensifiers, whereas the European media tend to be less emotive. It is worth noting that American newspapers apply different strategies in using metaphors. While The Washington Post refers to Russian history and famous films, The New York Times, as more progressive, deployed references to American household things (e.g. McDonald's). This pattern might indicate the intentions of American 
press to contrast Russia versus US wherein the former is associated with only negative manifestations.

Overall, the study attempted to explore a build-up of the evaluative meanings which lead to the construction of attitudes towards the Olympic discourse on Sochi 2014 in different national contexts (America and Europe). Despite some differences in the scale and variety of categories (see above), all newspapers use emotive language to emphasise and intensify their evaluation of the Games in order to prime the readers to make negative judgements on the Games as a whole. The Appraisal analysis of the news reports provides a more empirically justified account of the article's construal of a distinctive negative attitude not only to the sport event of the Games but also to the political and cultural life of the host country. The current findings add substantially to a growing body of literature on Olympic discourse analysis (or any other sport event) in the media and contributes to the study and application of the system of Appraisal in the analysis of news reports.

\section{References}

Al-Hejin, B. (2014) 'Covering Muslim women: Semantic macrostructures in BBC News', Discourse and Communication, 9 (1), 19-46

Baker, P., Gabrielatos, C., Khosravnik, M., Kryzanowski, M., McEnery, T. and Wodak, $\mathrm{R}$. 'A us eful methodological synergy? Combining critical discourse analysis and corpus linguistics to examine discourses of refugees and asylum seekers in the UK press', Discourse \& Society, 19(3), 273-306

Becker, A. (2011) 'Modality and engagement in British and German TV interviews' in K. Aijmer (ed), Contrastive pragmatics: special volume of Benjamins current topics, Amsterdam: John Benjamin, pp. 5-22

Benitez-Castro, M. and Hidalgo-Tenorio, E. (2019) 'Rethinking Martin \& White's affect taxonomy' in J. L. Mackenzie and L. Alba-Juez (eds), Emotion in Discourse, Amsterdam: John Benjamins, pp. 301-332

Bernstein, A., and Blain, N. (2003) Sport, media, culture: global and local dimensions. Sport in the global society, London: Frank Cass

Close, P., Xu, X., and Askew, D. (2006) The Beijing Olympiad: the political economy of a sporting mega-event, Abingdon and New York: Routledge

Espy, R. (1981) The politics of the Olympic Games. Berkeley, Los Angeles, London: University of California Press

Fairclough, N. (1992) Discourse and social change, Oxford, UK and Cambridge, MA: Polity Press and Blackwell 
Fairclough, N. (1995) Media Discourse, London: Edward Arnold

Fang, Y. (2001) 'Reporting the same events? A Critical Analysis of Chinese Print News Media Texts', Discourse \& Society, 12(5), 585-613

Fowler, R. (1991) Language in the news: discourse and ideology in the press, London: Routledge

Gales, T. (2009) 'Diversity' as enacted in US immigration politics and law: a corpusbased approach', Discourse \& Society, 20(2), 223-240

Gong, J. (2012) 'Re-Imaging an Ancient, Emergent Superpower: 2008 Beijing Olympic Games, Public Memory, and National Identity', Communication and Critical/Cultural Thinking, 9(2), 191-214

Hedenborga, S. (2013) 'The Olympic Games in London from a Swedish media perspective', International Journal of the History of Sport, 7, 789-804

Herman, E. S. and Chomsky, N. (1988) Manufacturing consent: the political economy of the mass media, London: Vintage Books

Higgs, C. T. and Weiller, K. H. (1994) 'Gender bias and the 1992 Summer Olympic Games: An analysis of television coverage', Journal of Sport and Social Issues, 18, 234-246

Hunston, S. (2011) Corpus approaches to evaluation: Phraseology and evaluative language, London: Routledge

Jullian, P. (2011) 'Appraising through someone else's words: the evaluative power of quotations in news reports', Discourse \& Society, 22(6), 766-780

Keen, S. (1986) Faces of the enemy: reflections of the hostile imagination, San Francisco: Harper and Row

Kim, K. (2014) 'Examining US news media discourses about North Korea: A corpusbased critical discourse analysis', Discourse \& Society, 25(2), 221-244

MacAloon, J. (2008) 'Legacy' as Managerial/Magical Discourse in Contemporary Olympic Affairs', The International Journal of the History of Sport, 25(14), 2060-2071

MacDonald, M. and Hunter, D. (2013) 'The discourse of Olympic security: London 2012', Discourse and Society, 24(1), 66-87

Martin, J. R. and Rose, D. (2003) Working with discourse, London: Continuum

Martin, J. R. and White, P. (2005) The language of evaluation; appraisal in English, London: Palgrave

O'Bonsawin, C. (2010) "No Olympics on stolen native land': contesting Olympic narratives and asserting indigenous rights within the discourse of the 2010 Vancouver Games', Sport in Society Cultures, Commerce, Media, Politics, 13 (1), 1968-2008

Statista (2018) 'Leading daily newspapers in the United States as of September 2017, by circulation' [online]. Available at https://www.statista.com/statistics/184682/usdaily-newspapers-by-circulation/. Accessed: 5 June 2018 
Tolson, A. (1996) Mediations: text and discourse in media studies, London: Arnold Urquhart, J. and Crossman, J. (1999) 'The Globe and Mail Coverage of the Winter Olympic Games A Cold Place for Women Athletes', Journal of Sport and Social Issues, 23(2), 193-202

van Dijk, T. A. (1995) 'Discourse semantics and ideology', Discourse \& Society, 6(2), 243-289

van Dijk, T. A. (1998) 'Opinions and ideologies in the press' in A. Bell and P. Garett (eds), Approaches to media discourse, Cambridge: Blackwell, pp. 21-63

Yang, G. and Jiang, M. (2015) 'The networked practice of online political satire in China: Between ritual and resistance', International Communication Gazette, 77(3), 215-231

Yang, M. (2015) 'Olympism and the Beijing Olympic Torch Relay in the British and Chinese Media Discourses: A Comparative Study', The International Journal of the History of Sport, 32(3), 499-515

Svitlana Tubaltseva did her Master degree in Applied Linguistics and TESOL at the University of Portsmouth in 2014. She has been teaching English and Linguistics in different countries across Europe and Asia. She has been involved in research on Olympic discourse, comparison of different national news reports, English as a lingua franca and methodological application of critical discourse analysis. Svitlana is now enrolled in her $\mathrm{PhD}$ program in Linguistics at the University of Roehampton. Her research interests are sociolinguistics, media discourse analysis, political discourse, news coverage, critical discourse analysis, corpus linguistics.

Email: svitlana.tubaltseva@gmail.com 